\title{
Financial Impact On The Accountability Of Malaysian State Islamic Religious Councils (SIRC)
}

\author{
Rosnia Masruki ${ }^{\mathrm{a}}$, Khaled Hussainey ${ }^{\mathrm{b}}$ and Doaa Aly $^{\mathrm{c}}$
}

\begin{abstract}
This paper aims to identify whether Malaysian State Islamic Religious Councils (SIRC) financial characteristics have a significant impact on the accountability of Malaysian State Islamic Religious Councils (SIRC). The content analysis approach is used to examine the extent and quality of disclosure in the annual reports of SIRC, indicating accountability of SIRCs. This paper uses the self-developed disclosure index that applies specifically for SIRC. Multiple regression is used to examine the financial determinants of the extent and quality of disclosure. The result of the regression models revealed that the extent and quality of SIRC disclosure is influenced by organisational characteristic, namely size. This study suggests that disclosure in the annual report, in particular the nonfinancial performance, increases with the amount of zakat collection, thereby demonstrating SIRC's responsibility. Next, the control variable of accessibility is found to be significantly related to financial statements. Obliged to produce financial statements, SIRC are more likely to disclose more information in the financial statements. This research finding has important implications for regulators, policy makers and top officials in SIRC, by monitoring the quality of disclosure, supporting the notion of public accountability, which appreciates the public's right to get inform about SIRC. Despite the voluntary disclosure of a non-financial report, SIRC should consider producing a comprehensive annual report for the discharge of their accountability and thus, encourage more funding. They should be more transparent to enhance accessibility, concerning the extent and quality of the disclosure.
\end{abstract}

Keywords: Financial, impact, accountability, disclosure, State Islamic Religious Councils.

\footnotetext{
a Senior Lecturer, Faculty of Economics and Muamalat, USIM, rosnia@usim.edu.my

b Professor of Accounting, Portsmouth Business School, UK, khaled.hussainey@ports.ac.uk

${ }^{c}$ Senior Lecturer, School of Business, Unviersity of Gloucestershire, UK, daly@glos.ac.uk
} 


\section{Introduction}

Odainkey \& Simpson (2013) posit that the establishment of an organisation is essential to characterise the disclosure information. Organisational structure and the obligation of functions are also important to understand the accountability (Lindkvist \& Llewellyn, 2003). The present study views a comprehensive annual report as a means for the discharge of accountability, supporting many previous studies (For e.g. Masruki et al., 2018; Ntim et al., 2016; Coy et al., 2001) SIRC are constitutionally under the Ruler's jurisdiction in the state administration as a result of colonialism period in 1874-195. The Ruler shall seek advice from the SIRC. Thus the SIRC has a unique status, which serves as an advisor for the State Ruler.

The Federal Constitution of Malaysia resembles British common law, which covers most areas of life and it is applied nationwide. Nevertheless, matters related to Islamic affairs are provided in Article 74 of the constitution, which grants every state the right to interpret Shariah. This law is applied to a person practicing the religion of Islam (Muslims) in respective regions. Under Islamic jurisdiction are the more social areas of family and religion, for example: marriage, divorce, dowry etc. Revenue likewise comes under their purview and includes: religious endowments (waqaf), alms (zakat) and treasury (baitulmal). Institutions operate within the states except for matters included in the Federal List in the constitution, when they are subject to State List authority like Muslim religious law, Islamic revenues and Malay reservation and custom. Consequently, the administration of Muslim wealth is carried out by the SIRC independently.

The establishment SIRC is headed by the Ruler in each state and the King respectively to administer Islamic law and to establish a state court system applying Islamic jurisprudence ${ }^{1}$. SIRC play charity roles that benefit Muslims and the local community. They are recognised as the highest statutory authority in the state, forming policy for Muslim revenue matters, written in the Ninth Schedule, Federal Constitution. SIRC are responsible for promoting the development of social welfare within the boundaries of Islam. As the SIRC were established in the public service setting, public accountability perspective is pertinent. The public has a right to be fully informed about the performance and condition of the public organisational setting (Coy et al., 2001), this information necessarily satisfying the needs of a broad range of stakeholders. This implies the uniqueness of SIRC, which play social roles in religious-based and public service setting. With this wide range functions, funding for SIRC's operations has become increasingly important.

In addition to financial assistance from government, they have other own fundings. Several types of funding characterise the flexibility of SIRC in managing their managerial operations (Siraj, 2012). Despite SIRC being established in accordance with the various state enactments, their main role to increase the well-being of the citizens is challenging, especially as far as

\footnotetext{
${ }^{1}$ However, in states with Rulers some statutes require that the Chief Minister advise the Ruler whereas others permit the SRCs to provide advice. In fact there are still some states, which do not provide clearly for any person to advise the Ruler. There is indeed a lack of uniformity in the SRC management structure.
} 
financial autonomy is concerned. The financial capacities of SIRC and the huge responsibilities they have been assigned, place demands for even greater efficiency for all SIRC in the foreseeable future (Mahamood, 2000)Although they are pursuant to the state government, financial provision from the state is limited compared to the federal SIRC. The federal government allocates a financial grant to the federal SIRC as it is governed directly by the Prime Minister's Department, showing that it has financial privilege over other SIRC.

Ministerial Functions Act 1969 (Act 2, amended 1999) declares that statutory bodies have power to lend, borrow, invest, establish subsidiary companies, manage funds and trust accounts, and implement activities and programmes. Although SIRC are entitled to obtain government grants every year, they are nevertheless encouraged to generate their own funds to finance their operations. Such wealth accumulation could enhance them to expedite socioeconomic development in their respective states. SIRC are subject to their own incorporation subsidiary legislation that outlines their purpose and powers of autonomy.

Mahamood (2000) argues that funding is one of the long-standing constraints for SIRC, preventing them from functioning effectively where the financial resources are not compatible with expected services, consequently affecting their future. However, the Malaysian government in the Ninth Malaysian Plan (2006-2010) has allocated RM250million ${ }^{2}$ (approximately GBP46.7million) specifically for improving the capacities of SIRC, which can benefit by financing their operations. Despite financial assistance from the state government and the federal government (through the state government) ${ }^{3}$, SIRC usually finance their operations using their own income generated from activities such as fees for the administrators of Muslims revenue, rental and investment income from commercial activities, endowed property received and donations from the public. In that case, this triggers the present study to examine whether financial characteristics such as size of SIRC, liquidity, leverage, efficiency and surplus have impact on the corporate disclosure of SIRC. Such disclosure is seen to be an important mechanism so that SIRC are held accountable and be seen as discharging their accountability.

\section{Literature Review}

Many disclosure studies examine the impact of financial motivation on the extent of disclosure in companies (e.g. Aly et al., 2010; Ghazali and Weetman, 2006; Brammer and Pavelin, 2004; Haniffa and Cooke, 2002; Wallaceet al.,1994) but a relative lack of studies about non-profit organisations such as local government, higher education institutions, charities, religious and other government agencies (e.g. Arshad et al., 2013; Bakar and Saleh, 2011a; Marcuccio and Steccolini, 2009; Ryan et al., 2002). As Broadbent and Guthrie (2008) state, there is less focus on the financial positions in public sector studies but this has progressed over time. The present study could fill the gap by contributing to such limited literature.

\footnotetext{
${ }^{2}$ GBP1 $=$ MYR5.36 on 13 December 2013.

${ }^{3}$ This is an exception for the federal SIRC where it obtains a direct financial grant from the federal government.
} 
This study aims to examine financial characteristics and whether they have any significant impact on the extent and quality of disclosure. The research hypotheses developed for this study are based on the following characteristics: size, liquidity, leverage, efficiency and surplus. These five characteristics have sub-categories to different types of disclosure, namely: a) annual report, b) non-financial and c) financial statements. Each category has been designated as: $a, b$ and c. Three control variables included are: stateownership, locality and accessibility.

\subsection{Explanatory variables: Financial characteristics}

\subsubsection{Size/wealth}

Previous studies argued that large organisations are more likely to disclose more information. Gandía and Archidona (2008) stated that wealthy organisations have incentives to increase information disclosure to show their quality of management, which benefits politicians, supporting politicaleconomy theory. They may have a promising opportunity for re-election. Similarly, Laswad et al. (2005) highlight the concern about political competition through disclosure. A significant and positive association was found in numerous studies such as Wallace et al. (1994), Hussainey et al. (2011) and Laswad et al. (2005). Therefore, this study posits both agency theory and political-economic theory, large organisations are more likely to provide more information to report their operations. However, Miniaoui and Oyelere (2013), Atan et al. (2012) and Aly et al. (2010) found no such association.

Size can be measured using total assets and total sales (Hussainey and AlNajjar, 2011; Aly et al., 2010 and Wallace et al., 1994). In this study, as the main role of SIRC is on zakat rather than sales, size is measured by total zakat collection. As the majority of studies have shown, size is significant and positively associated with the extent and quality of disclosure, as this study's hypotheses lists:

H1(a): Annual report disclosure is positively associated with size.

H1(b): Non-financial disclosure is positively associated with size.

H1(c): Financial statements disclosure is positively associated with size.

\subsubsection{Liquidity}

It has been argued that high liquidity organisations have higher agency costs, and thus are more likely to disclose more information to reduce such costs. They do this by showing their ability to pay current debt without liquidating other assets to satisfy stakeholders at large, consistent with agency theory and stakeholder theory. Several studies have examined the impact of liquidity on the extent of disclosure. However, the results are inconsistent. For instance, Wallace et al. (1994) found significant negative association, Arshad et al. (2013) and Owusu-ansah and Yeoh (2005) found positive association, whereas Aly et al.(2010) and Miniaoui and Oyelere (2013) did not find any association. Liquidity is measured by a ratio of current assets to current liability. Based on these discussions, in consistent with agency theory, 
mitigating asymmetric information between agency and principal and stakeholder theory, appreciating stakeholders' right to get information about SIRC, both theories indeed are used to underlie the context of this study. Thus, this study hypothesises that:

H2(a): Annual report disclosure is positively associated with liquidity

H2(b): Non-financial disclosure is positively associated with liquidity

$\mathrm{H} 2$ (c): Financial statements disclosure is positively associated with liquidity

\subsubsection{Leverage}

Reliance on debt is an important aspect of examining the financial position of an organization but it appears to be a little tested variable in terms of being used to explain disclosure in government, unlike studies about companies. From the perspective of agency theory, highly leveraged organisations are more likely to disclose more information due to the increase of agency cost. Indeed, more information disclosed can reduce the agency cost (Debreceny et al., 2002) while showing an ability to pay debt in a timely manner, in particular to creditors.

Several empirical studies have been conducted examining the association between leverage and information disclosure: the results are mixed. Laswad et al. (2005) found significant and positive association between leverage and disclosure whereas a negative association was found by Chiu and Wang (2015). Regarding another aspect, Lampkin and Raghavan (2008) proved that highly leveraged faith-based organisations negatively influenced government funding. Aly et al. (2010), Jaffar et al.(2007) and Debreceny et al.(2002) found no significant association. Leverage is measured by a ratio of debt to total assets. Based on the findings above, similar with Lampkin and Raghavan 's (2008), faith-based organisations like SIRC, this study hypothesises that: H3(a): Annual report disclosure is negatively associated with leverage H3(b): Non-financial disclosure is negatively associated with leverage H3 (c): Financial statements disclosure is negatively associated with leverage

\subsubsection{Efficiency}

Efficiency of distribution is the main concern of the public, rather than the contribution funds generated (Wahab and Rahman, 2011; Connolly and Hyndman, 2013), which shows the accountability to the public under the umbrella of public accountability, supporting stakeholder theory. The importance of efficiency has been found to be related to accountability discharge and funding decisions (Brammer and Millington, 2004; Heijden, 2013; Zainonet al., 2011). Both agency and stakeholder theory are pertinent in showing the accountability of the agent to the public.

Previous studies have been conducted using efficiency measures in relation to performance reporting and governance (Atan et al., 2013; Connolly and Hyndman, 2003; Dhanani and Connolly, 2012; Heijden, 2013; Zainon et al., 2011 and Callen et al., 2003). Nevertheless, to the best knowledge of the author, none have examined the impact of efficiency on the extent of disclosure. With regards to efficiency measurement, Connolly and Hyndman (2004)used a ratio of administration costs to total costs, Heijden (2013) used fundraising ratio expenses over collected funds whereas Sulaiman et al., 
(2009) used ratios of program expenses to total expenses, investment income to average investment and fundraising expenses to total related contributions. A ratio of fundraising expenses to total expenses, and administrative expenses to total expenses were used in Callen et al. (2003). As such, the basis of measuring efficiency is a ratio of expenses to total related expenses.

Despite the difficulty in measuring efficiency, and its sensitivity to, more meaningful information from the audited financial statement can be obtained by knowledgeable users (Connolly and Hyndman, 2013). Consistent with previous studies, efficiency is measured by a percentage of distribution funds to total generated income. Specifically, in this study the funds refer to zakat only because the main role of SIRC is derived from the zakat collection. For that reason, this study 6ypothesizes that:

H4(a): Annual report disclosure is positively associated with efficiency H4(b): Non-financial disclosure is positively associated with efficiency H4(c): Financial statement disclosure is positively associated with efficiency

\subsubsection{Surplus}

According to agency theory, a profitable organisation has a greater likelihood of disclosing more information to show their accountability to the public because the government is accountable to the public (Ghazali and Weetman, 2006). In the context of government, it refers to a surplus of entrusted funds which can benefit the citizen. On the other hand, it has been argued that less information is pertinent (Naser and Nuseibeh, 2003) probably due to the guarantee of reliance on government funding. Political connection is another contributing factor to such funding, as posited by Ghazali and Weetman (2006), although Mucciarone and Neilson (2011) found no such association. A significant and positive association was found between profitability and the extent of disclosure by Aly et al. (2010), Hussainey et al. (2011) and Haniffa and Cooke (2002) whereas negative association was discovered by Jaffar et al. (2007)and Hussainey and Al-Najjar (2011). However, Wallace et al. (1994) and Miniaoui and Oyelere (2013) found that profitability was not a significant in explaining disclosure.

This study uses a dummy variable of 1 if a surplus is earned, or otherwise zero, as a proxy of profitability. Consistent with the agency theory perspective within the banner of public accountability as argued above, this study hypothesises that:

H5(a): Annual report disclosure is positively associated with surplus H5(b): Non-financial disclosure is positively associated with surplus H5(c): Financial statement disclosure is positively associated with surplus

In general, the current research hypotheses were developed according to identified theoretical perspectives, previous empirical evidence and related factors concerning charities, NPO and public sector in general and in a Malaysian context, in particular SIRC. The measurements of each independent variable for this study are summarised in Table 1. 
Table1: Measurement of independent variables in the regression model

\begin{tabular}{ll}
\hline Variables & Measurements \\
\hline Size & Total zakat collection (log) \\
Liquidity & Current assets/Current liability \\
Leverage & Debt/Total assets \\
Efficiency & Distribution of zakat funds/Collection of zakat \\
Profitability & Dummy variable \\
\hline
\end{tabular}

\subsection{Control variables}

Three factors, namely: state ownership, locality and accessibility, have been found in previous studies which influence disclosure practices. For instance, Abdul-Rahman and Goddard (1998a) found that locality and state ownership influenced SIRC's disclosure. Coy and Dixon (2004) stated that accessibility is another contributing factor to the extent of disclosure but it was less tested (Bakar and Saleh, 2011a). Therefore, this study adopted these three factors as control variables.

\subsubsection{State-ownership}

It is political since the government has power to appoint the CEO and even board members. The appointed civil managers are held accountable to government interests, especially the public domain since political leaders of the government office are very concerned about their voting support. In the presence of government ownership, they are monitored by the public and are exposed to public criticism. Gandía and Archidona(2008) found that political competition positively influenced the extent of disclosure, which is consistent with political-economy and stakeholder theory. However, inconclusive results were observed in previous studies on the influence of government ownership and the extent of disclosure. Amran and Susela Devi (2008) found a significant positive association whereas a negative association was identified by Bushman et al. (2004)who argued that less disclosure protected politicians and their cronies. However, political connection and cronyism was not proven in Ghazali and Weetman (2006). In this study, state ownership is measured by the SIRC's governing body, either the government or opposition party. A dummy variable is used; one if the SIRC is controlled by the government party, otherwise zero. This study conjectures that the extent and quality of disclosure is positively associated with state ownership.

\subsubsection{Locality}

Bakar and Saleh (2011b) stated that location can explain the social incentive for disclosure in government. Abdul-Rahman and Goddard (1998a) found that the location of SIRC influenced their accounting practices. Those SIRC located in the city is more influenced by managerialist values with more power in financial decision-making. In contrast, another type of SIRC is characterised as a cultural power elite originating from the Royal family, have limited authority in decision-making. Such differences would indeed influence accounting disclosure practices. Mahamod (2011) found that locality has been proven to determine zakat collection, while the amount of distribution heavily depends on the zakat collection in which the SIRC is placed. Matsunagaet al. (2010) suggest that locality is related to size of NPO. 
Therefore, this study predicts that the extent and quality of disclosure will be associated with the locality of the SIRC.

\subsubsection{Accessibility}

It plays an important role in informing the public about the daily operations and activities of government entities. As Coy and Dixon (2004) suggest, internet availability is the easiest way to proxy accessibility. Styles and Tennyson (2007) and Bakar and Saleh (2011a) found a significant positive association of disclosure with accessibility. This indicates that the easier it is for the public to get access the annual reports, the higher the incentive to disclose more information in annual reports. This is consistent with stakeholder theory from the public accountability perspective. The public expects that an organisation is transparent and committed to publish information in their annual report. Grosso and Van Ryzin (2012) proved that disclosure is positively associated with the existence of web-reporting. In this study, two measures are used for proxy accessibility. Firstly, the existence of annual report on the SIRC's websites and secondly, availability of the annual report in SIRC to the public on request. Based on the above arguments, this study anticipates that the extent and quality of disclosure is positively associated with accessibility of disclosure.

\section{Method}

Disclosure index and regression are carried out to achieve the objective of this study; to identify the determinants of SIRC's annual reports using regression. The self-developed disclosure index is to empirically examine the SIRC's annual reports. The scores of extent and quality of disclosure are used to identify their association with the SIRC specific financial characteristics. There are several steps: determining criteria of the extent and quality of disclosure, the scoring method and addressing issues on validity and reliability, determining the annual reports sample, analysing data and screening data for regression.

\section{Results and Discussion}

This section provides the results of regression in order to answer the second objective in this study, specifically to identify the determinants of SIRC annual reports disclosure. Specifically, the purpose is to determine whether specific attributes of SIRC, such as size, liquidity, leverage, surplus and efficiency, have a significant impact on the extent and quality of disclosure. The disclosure refers to two types of reports, namely, annual reports, a combination of financial and non-financial disclosure items in an annual report, and financial statements. The research question for this objective is 'do SIRC characteristics affect their annual reports disclosure'?

\subsection{Descriptive statistics}

To evaluate the extent and quality of disclosure, three dependent variables were used respectively for scores of annual reports, and for non-financial and financial statement disclosure. The score is made up of the extent and quality scores. The independent variables employed were SIRC-specific characteristics such as size, liquidity, leverage, profitability and efficiency. 
Table 2 presents descriptive statistics of the dependent and independent variables.

Table 2: Descriptive statistics of variables

\begin{tabular}{|c|c|c|c|c|c|c|c|}
\hline Variables & Mean & Median & SD & Min & Max & Skewness & Kurtosis \\
\hline \multicolumn{8}{|l|}{ Dependent variable $(n=72)$} \\
\hline Annual Report & 52.20 & 41.74 & 15.55 & 33.31 & 76.40 & 0.330 & -1.743 \\
\hline Extent & 56.79 & 48.04 & 15.70 & 32.17 & 81.59 & 0.289 & -1.612 \\
\hline Quality & 47.61 & 36.70 & 15.71 & 27.80 & 73.20 & 0.350 & -1.695 \\
\hline Non-financial statement & 24.64 & 0.00 & 28.99 & 0.00 & 68.79 & 0.374 & -1.810 \\
\hline Extent & 24.33 & 0.00 & 28.63 & 0.00 & 66.66 & 0.373 & -1.818 \\
\hline Quality & 24.95 & 0.00 & 29.53 & 0.00 & 70.91 & 0.408 & -1.744 \\
\hline Financial statement & 79.76 & 80.89 & 4.61 & 66.61 & 86.61 & -1.479 & 1.797 \\
\hline Extent & 89.24 & 88.44 & 6.87 & 64.34 & 99.89 & -1.418 & 3.084 \\
\hline Quality & 70.28 & 71.11 & 4.48 & 55.56 & 75.56 & -1.903 & 3.755 \\
\hline \multicolumn{8}{|l|}{ Independent variables $(n=72)$} \\
\hline Size & 7.85 & 7.89 & 0.62 & 6.19 & 8.71 & -1.189 & 1.684 \\
\hline Liquidity & 15.46 & 8.83 & 18.58 & 1.34 & 89.54 & 2.604 & 6.698 \\
\hline Leverage & 0.20 & 0.10 & 0.26 & 0.01 & 1.14 & 2.136 & 4.114 \\
\hline Efficiency & 0.82 & 0.84 & 0.19 & 0.30 & 1.20 & -0.395 & -0.151 \\
\hline Surplus_dummy & 0.93 & 1.00 & 0.26 & 0.00 & 1.00 & -3.460 & 10.255 \\
\hline
\end{tabular}

As reported in Table 2, the mean score of disclosure for financial statement is higher $(79.76 \%)$ than for the annual report $(52.2 \%)$. Looking at the components of the annual report, the mean score of the financial statement $(79.76 \%)$ is much higher than that for non-financial statement items $(24.64 \%)^{4}$. Likewise, the extent and quality scores of disclosure show a similar trend to the final score of the report. In this study, it is therefore pertinent to investigate three different models of disclosure, which are the annual report, non-financial statement items and financial statements. The results of skewness and kurtosis reveal that all continuous variables are not normally distributed, which is similar to the Kolmogorov-Sminov and Shapiro-Wilk tests 5 .

Despite the non-normality of the data, the central limit theorem ${ }^{6}$ is pertinent to the theoretical justification (Gujarati \& Porter, 2009), so that a normality test can be used. Additionally, prior to the linear regression analysis, all variables in regression models must fulfil several conditions. In particular, empirical studies on accounting disclosure require attention to many issues such as normality of data distribution, outlier and linearity in multiple regression analysis (Cooke, 1998). This study is assumed to have normal data distribution and the parametric tests were pertinent.

\footnotetext{
${ }^{4}$ In this study, as for the sampled SIRC' annual reports ( $\left.\mathrm{n}=31\right)$, non-financial statement items will be investigated further while the financial statements are included in the entire financial statement variable $(\mathrm{n}=72)$.

${ }^{5}$ There is a deviation from normal data when the values of Skewness and Kurtosis are more or less than 0 , and the data is not normally distributed if the result is significant (Field, 2013).

${ }^{6}$ As the sample size is large, the assumption of normality matters less. The sample size is considered large if it is more than thirty (Field, 2013).
} 


\subsection{Multivariate analysis}

An Ordinary Least Square (OLS) regression was conducted to test the relationship between the dependent variables of the disclosure scores and the independent variables. The regression was initiated with a Pearson correlation test to identify any multicollinearity between independent variables and across variables. A correlations matrix was used to examine the correlations between all the independent and control variables. The results are presented in Table 3.

Table 3: Pearson correlation matrix across independent variables

\begin{tabular}{|c|c|c|c|c|c|c|c|c|c|}
\hline & Size & Liquidity & Leverage & Efficiency & Surplus & Locality & Ownshp & Web Report & Annual Report \\
\hline Size & 1 & & & & & & & & \\
\hline Liquidity & 0.128 & 1 & & & & & & & \\
\hline Leverage & -0.166 & -0.141 & 1 & & & & & & \\
\hline Efficiency & 0.053 & $-.232^{*}$ & $.334^{* *}$ & 1 & & & & & \\
\hline Surplus & 0.057 & -0.042 & $-.280^{*}$ & $-.383^{* x}$ & 1 & & & & \\
\hline Locality & -0.064 & $.280^{*}$ & $.272^{*}$ & -0.039 & -0.152 & 1 & & & \\
\hline Ownership & -0.214 & $-.282^{*}$ & -0.032 & 0.162 & -0.056 & $-.407^{* \pi}$ & 1 & & \\
\hline $\begin{array}{l}\text { Web } \\
\text { Report }\end{array}$ & $.494^{x-}$ & -0.12 & -0.193 & -0.057 & -0.024 & $-.533^{* \pi}$ & 0.189 & 1 & \\
\hline $\begin{array}{l}\text { Annual } \\
\text { Report }\end{array}$ & $.513^{*-}$ & 0.11 & -0.073 & -0.016 & 0.017 & $-.279^{*}$ & 0.032 & $.514^{* *}$ & 1 \\
\hline \multicolumn{10}{|c|}{$\cdots$. Correlation is significant at the 0.01 level (2-tailed). } \\
\hline - Correlatic & & gnificant at & $t$ the 0.05 & evel (2-tail & led). & & & & \\
\hline
\end{tabular}

Table 3 shows the highest correlation is 0.533 , which is below $0.7^{7}$. This indicates that there is no high correlation in any combination of independent variables, and thus multicollinearity is not a matter for concern. Next, all of the variables were tested in the regression model; the equations are expressed in Models 1, 2 and 3 below:

Model 1: $\mathrm{DAR}_{\mathrm{s}}=\beta_{0}+\beta_{1}$ Size $+\beta_{2}$ Liquidity $+\beta_{3}$ Leverage $+\beta_{4}$ Efficiency + $\beta_{5}$ Profitability $+\beta_{6}$ Ownership $+\beta_{7}$ Locality $+\beta_{8}$ Accessibility $+\sum_{\mathrm{s}}$

Model 2: DNFS $_{\mathrm{s}}=\beta_{0}+\beta_{1}$ Size $+\beta_{2}$ Liquidity $+\beta_{3}$ Leverage $+\beta_{4}$ Efficiency + $\beta_{5}$ Profitability $+\beta_{6}$ Ownership $+\beta_{7}$ Locality $+\beta_{8}$ Accessibility $+\sum \mathrm{s}$

Model 3: $D F S_{s}=\beta_{0}+\beta_{1}$ Size $+\beta_{2}$ Liquidity $+\beta_{3}$ Leverage $+\beta_{4}$ Efficiency + $\beta_{5}$ Profitability $+\beta_{6}$ Ownership $+\beta_{7}$ Locality $+\beta_{8}$ Accessibility $+\sum \mathrm{s}$

where,

$\mathrm{DAR}_{\mathrm{s}}=$ Annual Report Score

DNFS $_{\mathrm{s}}=$ Non-Financial Statement Score

DFS $=$ Financial Statement Score

$\beta=$ the constant coefficient

$\sum_{\mathrm{s}}=$ the error term

The above three models are used in the regression equation. Each model is sub-divided into Models a and $b$ for the extent and quality of disclosure respectively. This is because the final score of disclosure is made up of the extent and quality score. The conclusion is based on the robust findings, where these are supported by both Model $a$ and Model $b$.

${ }^{7}$ Correlation above 0.7 is defined as highly correlated (Pallant, 2013) 
Prior to the linear regression analysis, all variables in regression models must fulfil several conditions. In particular, empirical studies on accounting disclosure require attention to plenty of issues such as the multicollinearity and heteroscedasticity in multiple regression analysis (Cooke, 1998). Table 4 addresses such issues in all regression models.

Based on Table 4, the highest VIF is 2.263 , which is below 10 . This indicates that multicollinearity is not a concern in all regression models. The highest Cook's distance is 0.203 , which is less than 1 and the standardised residual is less than 3.3, indicating no outliers. As such, it can be concluded that heteroscedasticity does not pose any problems in the models. Relevant tests have been inspected to ensure that the underlying assumptions of the OLS regression analysis are not violated. 


\section{Table 4: Regression results}

\begin{tabular}{|c|c|c|c|c|c|c|c|c|c|c|c|c|c|c|c|c|c|c|c|}
\hline & \multirow{2}{*}{$\begin{array}{c}\text { Expected } \\
\text { sign } \\
\end{array}$} & \multicolumn{2}{|c|}{ Model 1 (AR) } & \multicolumn{2}{|c|}{ Model 2 (NFS) } & \multicolumn{2}{|c|}{ Model 3 (FS) } & \multicolumn{2}{|c|}{ Model 1a } & \multicolumn{2}{|c|}{ Model $1 \mathrm{~b}$} & \multicolumn{2}{|c|}{ Model 2a } & \multicolumn{2}{|c|}{ Model $2 \mathrm{~b}$} & \multicolumn{2}{|c|}{ Model 3a } & \multicolumn{2}{|c|}{ Model $3 b$} \\
\hline & & coefficient & t t-stat & coefficient & tt t-stat & coefficient & it t-stat & coefficient & t-stat & coefficient & t t-stat & coefficient & t t-stat & coefficient & t-stat & coefficient & t t-stat & coefficient & tt $t$-stat \\
\hline Constant & & & & & -2.028 & & 10.996 & & & & & & & & & & & & \\
\hline Size & + & $0.348^{* * *}$ & 2.563 & $0.391 * *$ & 2.927 & $-0.315^{\circ *}$ & -2.446 & $0.37^{* * *}$ & 2.695 & $0.320^{* *}$ & 2.382 & $0.403^{* * *}$ & 3.008 & $0.377^{* * *}$ & 2.821 & $-0.273^{* *}$ & -2.048 & $-0.229^{*}$ & -1.892 \\
\hline Liquidity & + & 0.19 & 1.652 & 0.158 & 1.401 & $0.204^{*}$ & 1.758 & 0.207 & 1.785 & 0.169 & 1.486 & 0.153 & 1.354 & 0.162 & 1.433 & $0.275^{* *}$ & 2.283 & $\cdot 0.001$ & -0.009 \\
\hline Leverage & . & 0.114 & 0.961 & 0.129 & 1.106 & -0.107 & -0.895 & 0.13 & 1.087 & 0.096 & 0.817 & 0.125 & 1.073 & 0.131 & 1.128 & 0.018 & 0.145 & $-0.248^{\circ *}$ & -2.204 \\
\hline Efficiency & + & $\cdot 0.047$ & $\cdot 0.375$ & $\cdot 0.09$ & -0.728 & $0.273^{* *}$ & 2.236 & -0.008 & -0.062 & -0.085 & $\cdot 0.684$ & $\cdot 0.08$ & -0.646 & $\cdot 0.099$ & -0.8 & $0.379^{* * *}$ & 3.003 & -0.021 & -0.186 \\
\hline Surplus & + & 0.009 & 0.074 & $\cdot 0.02$ & $\cdot 0.174$ & 0.189 & 1.635 & 0.011 & 0.096 & 0.006 & 0.053 & -0.031 & -0.262 & -0.01 & -0.086 & $0.238^{\circ}$ & 1.992 & 0.023 & 0.210 \\
\hline \multicolumn{2}{|c|}{ State ownership } & -0.042 & $\cdot 0.348$ & 0.001 & 0.01 & $-0.318 * \cdots$ & -2.648 & -0.017 & -0.14 & -0.066 & -0.551 & 0.01 & 0.082 & -0.007 & -0.061 & -0.168 & -1.350 & $-0.397 * * *$ & -3.516 \\
\hline Locality & & -0.229 & -1.601 & $\cdot 0.218$ & -1.553 & -0.074 & $\cdot 0.575$ & $-0.303^{* *}$ & -2.099 & $\cdot 0.15$ & -1.06 & -0.226 & -1.6 & -0.21 & -1.492 & $-0.244^{\circ}$ & -1.825 & $0.221^{\circ}$ & 1.828 \\
\hline \multicolumn{2}{|c|}{ Accessibility } & 0.207 & 1.345 & 0.204 & 1.354 & $0.504 * *$ & 3.919 & 0.123 & 0.795 & $0.286^{\circ}$ & 1.881 & 0.186 & 1.226 & 0.221 & 1.465 & $0.328^{* *}$ & 2.467 & $0.532^{* * *}$ & 4.404 \\
\hline \multicolumn{20}{|c|}{ significant at ${ }^{*} 0.10, " * 0.05, \cdots * 0.01$} \\
\hline \multicolumn{2}{|c|}{ F-value } & \multicolumn{2}{|c|}{$4.099 * *$} & \multicolumn{2}{|c|}{$4.522 * *$} & \multicolumn{2}{|c|}{$3.981^{* * *}$} & \multicolumn{2}{|c|}{$3.885 * *$} & \multicolumn{2}{|c|}{$4.361 * *$} & \multicolumn{2}{|c|}{$4.446 * *$} & \multicolumn{2}{|c|}{$4.532 * *$} & \multicolumn{2}{|c|}{$3.188 * * *$} & \multicolumn{2}{|c|}{$5.561 * * *$} \\
\hline \multicolumn{2}{|c|}{ Adjusted $R^{2}$} & \multicolumn{2}{|c|}{$25.90 \%$} & \multicolumn{2}{|c|}{$28.40 \%$} & \multicolumn{2}{|c|}{$25.10 \%$} & \multicolumn{2}{|c|}{$24.50 \%$} & \multicolumn{2}{|c|}{$27.50 \%$} & \multicolumn{2}{|c|}{$28.00 \%$} & \multicolumn{2}{|c|}{$28.40 \%$} & 19.8 & & 33.90 & \\
\hline Std. R & esidual & -3.4 & & -3.38 & 387 & -4.47 & & -3.34 & & -3.6 & & -3.45 & & -3.4 & & -4.8 & & -3.9 & \\
\hline Max Cool & Is distance & 0.1 & & 0.17 & 175 & 0.14 & & 0.152 & & 0.20 & & 0.16 & & 0.17 & & 0.1 & & 0.29 & \\
\hline $\mathrm{Ma}$ & XVIF & 2.2 & & 2.26 & 263 & 1.57 & & 2.263 & & 2.26 & & 2.26 & & 2.26 & & 1.5 & & 1.57 & \\
\hline
\end{tabular}




\subsection{Financial Characteristics}

Table 4 shows that the F-value for all models is significant at the $1 \%$ level. The adjusted $\mathrm{R}^{2}$ indicates that the independent variables used in the study can explain about $25 \%$, $28 \%$ and $20 \%$ of the extent and quality of disclosure for annual reports, non-financial and financial statements respectively. It discusses the results of regression according to the eight tested characteristics. These are size, liquidity, leverage, efficiency and surplus; control variables such as state ownership, locality of SIRC and accessibility are taken into consideration.

\subsubsection{Size of SIRC}

From Table 4 above, it can be seen that the association between the size of a SIRC and the annual report and non-financial disclosure was positive and significant (at 1\% level) in Models 1 and 2. Therefore, Hypotheses 1a and 2a are supported. In particular, the extent of annual reports and non-financial disclosure was statistically significant at $1 \%$ in Model 1a and Model 2a, whereas the quality of annual reports was significant at $5 \%$ and $1 \%$ respectively in Model $1 \mathrm{~b}$ and $2 \mathrm{~b}$.This suggests that the extent and quality of annual reports and non-financial disclosure have the same impact on size. A possible explanation for this positive relationship is due to the fact that the majority of SIRC are led by politicians ${ }^{11}$, a fact which motivates more disclosure for political support. Indeed, this study supports the political economy theory and the agency theory that are consistent with many other studies (Hussainey et al., 2011; Laswad et al., 2005; Christensen and Mohr, 2003; Wallace et al 1994).

In Model 3, although size reported a significant result, the negative coefficient contradicts the expected direction. Hypothesis 1c, which predicts a significant and positive association between size and the financial statement disclosure, is not supported by this study. The negative and significant association was also observed between the extent and quality of financial statements in Model 3a and 3b with size. The negative association indicates that the larger organizations tend to disclose less information than small organizations to avoid political intervention from the public. As such, it is inconsistent with the underlying public accountability.

\subsubsection{Liquidity}

It was observed that liquidity was significant, at a $10 \%$ level, and positively related to the financial statement disclosure in Model 3. The extent of disclosure in Model 3a was also significant at 5\% level. However, this was not the case for Model $3 \mathrm{~b}$ and therefore, the findings are not robust enough to accept Hypothesis 2c. This study suggests that there is a different determinant, of the extent and quality of financial statements, in relation to liquidity. Such determinant between the extent and quality of disclosure is also found by Alotaibi and Hussainey (2016).

In this study, the non-significant relationship was observed for both annual reports and non-financial statements in Model 1 and 2 and their sub-models. Therefore, Hypotheses $2 \mathrm{a}$ and $2 \mathrm{~b}$ are not supported. Likewise, liquidity failed to provide any evidence supporting the relationship between liquidity and disclosure for all models. This nonsignificant finding indicates that liquidity is not significant and positively associated

\footnotetext{
${ }^{11}$ Only four SIRC are chaired by the State Ruler while others are led by the Chief Minister or a corporate person.
} 
with the extent and quality of the disclosure of annual reports, and non-financial and financial statement disclosure. This finding is also in line with Aly et al. (2010) and Owusu-Ansah (1998).

\subsubsection{Leverage}

Leverage was found to be negative and significant (at 5\% level) in Model 3b. However, Model 3 in fact was insignificant. Therefore, the findings are not robust enough to support the hypothesis. This study concludes that leverage is not statistically associated with the extent and quality of financial statement disclosure. Hypothesis $3 \mathrm{c}$ is rejected, although the negative relationship confirms the expected positive sign. A nonsignificant relationship was observed between the annual report and non-financial disclosure and leverage in Model 1 and 2. The non-significant relationship between leverage and disclosure was also documented in the literature (Ntim et al., 2016; Jaffar et al., 2007 and Gordon et al., 2002).

\subsubsection{Efficiency}

A significant of 5\% level and positive association in Model 3 was found between efficiency and the financial statement disclosure. Although a significant and positive direction was also observed in Model 3a (at 1\% level), Model 3b was not significant. This study suggests that the extent and quality of financial statements have a different impact on the efficiency. As the result is supported by Model 3a only, it is concluded that efficiency is not statistically related with the financial statement, rejecting Hypothesis $4 \mathrm{c}$. Other hypotheses $4 \mathrm{a}$ and $4 \mathrm{~b}$ are also rejected.

The non-significance association however, depends on the measurement of disclosure whether the extent, quality or both is used. This finding contributes to the determinants of SIRC efficiency through disclosure, in addition to factors such as a computerised zakat system, zakat payment and decentralisation (Wahab and Rahman, 2011). The importance of efficiency is highlighted by Heijden (2013) for more effective fundraising. This matter is crucial to attract more funding in the NPO.

\subsubsection{Surplus}

This study did not find evidence to support a significant relationship between surplus and the disclosure of SIRC. Although it was found that there was a significant, positive relationship between surplus and the extent of financial statement disclosure at $10 \%$ level in Model 3a, basically Model 3 was not significant. Therefore, there is not enough evidence to support Hypothesis 5c. Similarly regarding efficiency, both Hypotheses 5a and $5 \mathrm{~b}$ are not accepted.

The non-significant relationship was also reported by Chiu and Wang (2015). This is probably due to the different study context and proxy used in this study. They used the amount of profitability to measure profit whereas this study used 0 or 1 to represent the surplus or deficit respectively ${ }^{12}$. Overall, in this study, profitability appears not to be

\footnotetext{
${ }^{12}$ The profitability variable was also tested using an Independent $t$-test, the results indicating that there is no significant difference ( $\mathrm{p}$-value $=0.682$ ) in disclosure between SIRC with surplus and deficit.
} 
significantly associated with the SIRC disclosure, which has led to the non-significant difference between surplus and deficit SIRC in disclosure.

\subsection{Control Variables}

\subsubsection{State-Ownership}

In this study, it was revealed that state-ownership was negative and significant at $1 \%$ level in Model 3. This was supported by the quality of financial statement disclosure in Model 3b, but the extent of disclosure in Model 3a was not significant, implying that the extent and quality of disclosure have a different impact (Alotaibi and Hussainey, 2016), particularly on state ownership. Although the variable was significant, the negative coefficient contradicts the expected positive. Therefore, the state ownership variable is not supported, indicating that state-ownership is not related to the financial statement disclosure in Model 3.

In spite of the non-significance, the negative coefficient applies also to the annual report disclosure in Model 1. This suggests that SIRC governed by a government party disclose less information in their financial statements, than SIRC governed by an opposition party. Fundamentally, comprehensive disclosure is limited to minimize the possibility of political action, as posited by Wallace et al., (1994). The non-significance of state ownership is consistent with the findings of Ghazali and Weetman (2006).

A positive prediction was observed for non-financial disclosure in Model 2, which is not significant. The positive sign implies that state-owned SIRC appear to disclose more information in their annual reports than is given in their financial statements, as claimed in political-economy theory. In this study, this theory is not supported. A possible explanation for this positive association is due to the SIRC resolution and accountability index ${ }^{13}$ which has led to a transparency of disclosure among them. The non-significance of this factor means that more efforts should be taken by the government to enhance voluntary disclosure by all government agencies, and in particular, by state-owned SIRC.

\subsubsection{Locality}

This study did not find any evidence to support the hypothesis that there is a significant association between locality and the disclosure scores of annual reports and both types of sub-reporting, namely, non-financial statements and financial statements. Looking at the sub-models, it was found that the extent of annual reports in Model 1a was significant, at $5 \%$ level, and the extent and quality of financial statements respectively in Model 3a and 3b (at 10\% levels). This study suggests that the extent and quality of financial statement disclosure might have a similar impact on the locality. However, it was found that the locality was not significant for annual reports, non-financial and financial statements in Model 1, 2 and 3. Therefore, there is not enough evidence to support this variable. The non-significant association contradicts Archambault and Archambault (2003) and Haniffa and Cooke (2002) with an argument indicating that culture has a significant influence on the disclosure. In this study, the locality of SIRC identifies their culture (Abdul-Rahman and Goddard, 1998).

\footnotetext{
${ }^{13}$ See Section 1.3 for details of the resolution and accountability index.
} 


\subsubsection{Accessibility}

Only in Model 3 was accessibility found to be positive and statistically significant, at $1 \%$ level, for the financial statements. The significant association was also found in the extent, at 5\% level, and quality, at $1 \%$ level, of financial statements in Models $3 \mathrm{a}$ and $3 \mathrm{~b}$ respectively. Indeed, this finding provides evidence to support the hypothesis that accessibility could enhance disclosure (Coy et al., 2001). The extent and quality of the financial statements is related to accessibility. The positive coefficient suggests that SIRC that prepare annual reports allow easy accessibility to the public and appear to disclose more information. A similar finding was also documented by Bakar and Saleh (2011). The financial statement allows experienced readers to extract information from the audited financial statement to meet their needs (Connolly and Hyndman, 2013).

In sum, consistent with the notion of public accountability, Ntim et al. (2016) suggest that disclosure should focus not only on the financial performance of the reporting entity, but also on the voluntary disclosure of the non-financial report. Furthermore, they state that such a comprehensive report could satisfy the powerful stakeholders and result in the emergence of new stakeholders to broaden public accountability beyond the private, enabling a more sustainable operation. Supporting the roles of SIRC being accountable to the public, is also in accordance with Shariah. The comprehensive report evaluated in this study is thereby pertinent. Other environmental factors, such as political, economic and social issues, could also influence disclosure practices (Hussainey and Al-Nodel, 2008).

\section{Conclusion}

Within the purview of accountability, the aim of this study is to look at the financial impact of Malaysian State Islamic Religious Councils (SIRC) on their information disclosure in the annual reports. Looking at the results of the regression models, it was revealed that the extent and quality of SIRC disclosure are influenced by organisational characteristic, namely size. This study suggests that disclosure in the annual report, in particular the non-financial performance, increases with the amount of zakat collection, thereby demonstrating SIRC's responsibility, as suggested by political economy theory. This could minimize agency costs, which therefore supports the agency theory consistent with Islamic accountability, with an expectation of full disclosure (Baydoun and Willett, 2000). This point is supported by Khaled and Nodel (2008), who suggest that the social factors of a religion such as Islam could influence the disclosure.

Next, the control variable of accessibility was found to be significantly related to financial statements. Obliged to produce financial statements, SIRC are more likely to disclose more information in the financial statements. Such accessibility to financial statements allows users to know more about SIRC as a result, and similarly the wide range of stakeholders, supporting stakeholder theory. Requested information might concern the zakat collection and the distribution of funds, disclosed in the notes to the accounts.

These findings have important implications for regulators, policy makers and top officials in SIRC, by monitoring the quality of voluntary and mandatory disclosure, and supporting the whole notion of public accountability. Despite the voluntary disclosure of a non-financial report, SIRC should consider producing a comprehensive annual 
report for the discharge of their accountability. They should be more transparent to enhance accessibility, concerning the extent and quality of the disclosure. Consequently, dissatisfaction and inquiry about their accountability might be avoided (Wahab and Rahman, 2011), and thus, encourage more funding (Heijden, 2013; Lampkin and Raghavan, 2008; Muda et al., 2006).

To conclude, the main findings in this study are robust in several regression models, since they are supported by the extent and quality of disclosure. Although there was no intention to differentiate the impact of the extent and quality of disclosure, the results showed that the relationship strength and the coefficient signs might also be different between the measurements. The arguments of Alotaibi and Hussainey (2016) and Chakroun and Hussainey (2014) claim that the quantity (in this study is the extent) and quality of disclosure may produce different significant regression results. Therefore, the results should be taken with caution. Despite the fact that this research has attempted to ensure the reliability and validity of this quantitative study, there are nevertheless several limitations. The slightly low explanatory power of the three different models, about 20\%-25\%, shows that there are other factors which can explain the SIRC disclosure. For instance, such factors could be the inconsistency of the annual report publications, the absence of annual reports for several SIRC and the difficulty in quantifying several variables.

The unavailability of information also limited the present study to examining corporate governance mechanisms which might have influenced the disclosure, as proven in many disclosure studies (Ntim et al., 2016; Karaa, 2013; Hyndman and McDonnell, 2009; Hussainey and Al-Nodel, 2008; Barros and Nunes, 2007; Haniffa and Cooke, 2005). However, nowadays SIRC are becoming more active in producing annual reports, and future studies could examine the annual reports of SIRC more comprehensively in relation to corporate governance mechanisms. As an alternative to the limited secondary data in this study, interviews is suggested for future studies to satisfy the needs of a wide range of stakeholders.

\section{References}

Abdul-Rahman, A. R., \& Goddard, A. (1998). An interpretive inquiry of accounting practices in religious organisations. Financial Accountability and Management, 14(3), 183-201.

Aly, D., Simon, J., \& Hussainey, K. (2010). Determinants of corporate internet reporting: evidence from Egypt. Managerial Auditing Journal, 25(2), 182-202.

Amran, A., \& Susela Devi, S. (2008). The impact of government and foreign affiliate influence on corporate social reporting. Managerial Auditing Journal, 23(4), 386404.

Arshad, R., Bakar, N. A., Sakri, F. H., \& Omar, N. (2013). Organizational Characteristics and Disclosure Practices of Non-profit Organizations in Malaysia. Asian Social Science, 9(1), 209-217.

Atan, R., Zainon, S., Nam, R. Y. T., \& Aliman, S. (2012). Analyzing Disclosure Practice of Religious Nonprofit Organizations using Partial Disclosure Index. World Academy of Science, Engineering and Technology, 68, 1389-1395.

Atan, R., Zainon, S., \& Wah, Y. B. (2013). Empirical Evidence of Governance and Disclosure in Charity Organizations. Journal of Basic and Applied Scientific Research, 3(1), 533-542. 
Bakar, N. B. A., \& Saleh, Z. (2011a). Disclosure of accountability information in public sector: The case of Malaysian Federal Statutory Bodies. In 13th Biennial CIGAR Conference: Bridging public sector and non-profit sector accounting (pp. 1-38). Ghent.

Bakar, N. B. A., \& Saleh, Z. (2011b). Incentives for Disclosure of Accounting Information in Public Sector: A Literature Survey. International Research Journal of Finance and Economics, (75).

Brammer, S., \& Millington, A. (2004). The Development of Corporate Charitable Contributions in the UK: A Stakeholder Analysis. Journal of Management Studies, 41(8), 1411-1434.

Brammer, S., \& Pavelin, S. (2004). Voluntary social disclosures by large UK companies. Business Ethics: A European Review, 13(July), 86-99.

Broadbent, J., \& Guthrie, J. (2008). Public sector to public services: 20 years of "contextual" accounting research. Accounting, Auditing \& Accountability Journal (Vol. 21).

Bushman, R. M., Piotroski, J. D., \& Smith, A. J. (2004). What determines corporate transparency? Journal of Accounting Resea, 42(2), 207-252.

Callen, J. L., Klein, A., \& Tinkelman, D. (2003). Board Composition, Committees, and Organizational Efficiency: The Case of Nonprofits. Nonprofit and Voluntary Sector Quarterly, 32(4), 493-520.

Chiu, T.-K., \& Wang, Y.-H. (2015). Determinants of Social Disclosure Quality in Taiwan: An Application of Stakeholder Theory. Journal Business Ethics, 379398.

Connolly, C., \& Hyndman, N. (2003). Performance reporting by UK charities: Approaches, difficulties and current practice. Edinburgh, UK.

Connolly, C., \& Hyndman, N. (2004). Performance reporting: a comparative study of British and Irish charities. The British Accounting Review, 36(2), 127-154.

Connolly, C., \& Hyndman, N. (2013). Towards Charity Accountability. Public Management Review, (August 2013), 1-24.

Coy, D., \& Dixon, K. (2004). The public accountability index: crafting a parametric disclosure index for annual reports. The British Accounting Review, 36(1), 79106.

Coy, D., Fischer, M., \& Gordon, T. (2001). Public accountability: A new paradigm for college and university annual reports. Critical Perspectives on Accounting, 12(1), $1-31$.

Debreceny, R., Gray, G. L., \& Rahman, A. (2002). The determinants of Internet financial reporting. Journal of Accounting and Public Policy, 21(4-5), 371-394.

Dhanani, A., \& Connolly, C. (2012). Discharging not-for-profit accountability: UK charities and public discourse. Accounting, Auditing \& Accountability Journal, 25(7), 1140-1169.

Gandía, J. L., \& Archidona, M. C. (2008). Determinants of web site information by Spanish city councils. Online Information Review, 32(1), 35-57.

Ghazali, N. A. M., \& Weetman, P. (2006). Perpetuating traditional influences: Voluntary disclosure in Malaysia following the economic crisis. Journal of International Accounting, Auditing and Taxation, 15, 226-248.

Grosso, A. L., \& Van Ryzin, G. G. (2012). How citizens view government performance reporting. Public Performance \& Management Review, 35(2), 235-250.

Gujarati, D. N., \& Porter, D. (2009). Basic Econometrics. Mc-Graw Hill.

Haniffa, R. M., \& Cooke, T. E. (2002). Culture, Corporate Governance and Disclosure in Malaysian Corporations. Abacus, 38(3), 317-349. 
Heijden, H. Van Der. (2013). Small is beautiful? Financial efficiency of small fundraising charities. The British Accounting Review, 45(1), 50-57.

Hussainey, K., \& Al-Najjar, B. (2011). Future-oriented narrative reporting: determinants and use. Journal of Applied Accounting Research, 12(2), 123-138.

Hussainey, K., Elsayed, M., \& Razik, M. A. (2011). Factors affecting corporate social responsibility disclosure in Egypt. Corporate Ownership \& Control, 8(4), 315388.

Jaffar, R., Riduan, M., \& Abdul, C. (2007). Determinant factors affecting quality of reporting in annual report of Malaysian companies. Malaysian Accounting Review, 6(2), 19-43.

Lampkin, L., \& Raghavan, K. (2008). Organisational characteristics, financial performance measures and funding soures of faith based organisations. Journal of Health and Human Services Administration, 31(3), 332-355.

Laswad, F., Fisher, R., \& Oyelere, P. (2005). Determinants of voluntary Internet financial reporting by local government authorities. Journal of Accounting and Public Policy, 24(2), 101-121.

Lindkvist, L., \& Llewellyn, S. (2003). Accountability, responsibility and organization. Scandinavian Journal of Management, 19(2), 251-273.

Mahamod, L. H. (2011). Alleviation of rural poverty in Malaysia: the role of Zakat, a case study. University of Edinburgh.

Mahamood, S. M. (2000). The administration of waqf, pious endowment in Islam: A critical study of the role of the State Islamic Religious Councils as the sole trustess of awqaf assets and the implementation of istibdal in Malaysia with special reference to the Federal Territory . University of Birmingham.

Marcuccio, M., \& Steccolini, I. (2009). Patterns of voluntary extended performance reporting in Italian local authorities. International Journal of Public Sector Management, 22(2), 146-167.

Masruki, R., Khaled Hussainey, \& Aly, D. (2018). Developing Accountability Disclosure Index for Malaysian State Islamic Religious Councils (SIRCs): Quantity and Quality. Journal of Management and Accounting, 17(1), forthcoming.

Matsunaga, Y., Yamauchi, N., \& Okuyama, N. (2010). What Determines the Size of the Nonprofit Sector?: A Cross-Country Analysis of the Government Failure Theory. VOLUNTAS: International Journal of Voluntary and Nonprofit Organizations, 21(2), 180-201.

Miniaoui, H., \& Oyelere, P. (2013). Determinants of Internet Financial Reporting Practices: Evidence from the UAE. Review of Pacific Basin Financial Markets and Policies, 16(4), 1-25.

Mucciarone, M. A., \& Neilson, J. (2011). Performance reporting in the Malaysian government. Asian Academy of Management Journal of Accounting and Finance, $7(2), 35-77$.

Naser, K., \& Nuseibeh, R. (2003). Quality of financial reporting: evidence from the listed Saudi nonfinancial companies. The International Journal of Accounting, $38(1), 41-69$.

Ntim, C. G., Soobaroyen, T., \& Broad, M. J. (2016). Governance structures, Voluntary disclosures and public accountability: The case of UK Higher Education Institutions. Accounting, Auditing and Accountability Journal, 44.

Odainkey, H. N., \& Simpson, S. N. Y. (2013). Ensuring accountability in state-owned enterprises : Examining the role of annual reports from a middle income country's perspective. The Journal of Institute of Public Enterprise, 36(1\&2), 1-20. 
Owusu-ansah, S., \& Yeoh, J. (2005). The Effect of Legislation on Corporate Disclosure Practices. ABACUS, 41(1), 92-109.

Palmer, P., \& Vinten, G. (1998). Accounting, auditing and regulating charities towards a theoretical underpinning. Managerial Auditing Journal, 13(6), 346355.

Ryan, C., Stanley, T., \& Nelson, M. (2002). Accountability disclosures by Queensland Local Government Councils: 1997-1999. Financial Accountability \& Management, 18(3), 261-289.

Siraj, S. A. (2012). An empirical investigation into the accounting, accountability and effectiveness of waqaf management in the State Islamic Religious Councils (SIRCs) in Malaysia. Cardiff University.

Styles, A. K., \& Tennyson, M. (2007). The accessibility of financial reporting of US municipalities on the internet. Journal of Public Budgeting, Accounting and Financial Management, 19(1), 56-92.

Sulaiman, M., Adnan, M. A., \& Nor, P. N. S. M. M. (2009). Trust Me! A Case Study of the International Islamic University Malaysia' s Waqf Fund. Review of Islamic Economics, 13(1), 69-88.

Wahab, N. A., \& Rahman, A. R. A. (2011). Efficiency of Zakat Institutions and Its Determinants. In 8th International conference on Islamic economics and finance (pp. 1-19).

Wallace, R. S. O., Naser, K., \& Mora, A. (1994). The Relationship Between the Comprehensiveness of Corporate Annual Reports and Firm Characteristics in Spain. Accounting and Business Research, 25(97), 41-53.

Zainon, S., Atan, R., Wah, Y. B., \& Nam, R. Y. T. (2011). Institutional donors' expectation of information from the non-profit organizations (NPOs) reporting: A pilot survey. International NGO Journal, 6(8), 170-180. 